\title{
DOUBTS OF THE TSL ENTERPRISES TO SOCIAL RESPONSIBILITY - AN EMPIRICAL STUDY BASED ON THE RESULTS OF RESEARCH
}

\section{IZABELA DEMBIŃSKA}

University of Szczecin, POLAND

e-mail: izabela.dembinska@wzieu.pl

\begin{abstract}
RECEIVED
25 February 2018

ACCEPTED

20 September 2018

JEL

CLASSIFICATION

L9, M14

KEYWORDS

corporate social responsibility, ISO 26000 , transport and logistics enterprises

ABSTRACT

The article presents the doubts and negative attitude of companies towards corporate social responsibility. Companies from the TSL sector were used as an example. Considerations divided into two parts: theoretical and empirical. In the theoretical part, was reviewed literature together with respond to the problems identified. The purpose of this section was to indicate that doubts and criticisms which are presented in the case of social responsibility. In the empirical part were quoted research results, based on which were defined objections to the social responsibility that the company of the TSL formulate, and their causes.
\end{abstract}

\section{Introduction}

Criticism of the idea of social responsibility has already appeared in the early sixties of the twentieth century due to doubts about the sense of applying the concept of social responsibility in the company, propounded by Milton Friedman. He was even widely regarded as the creator of a critical approach to the concept of social responsibility. He claimed (Friedman, 1970; Sternberg, 1994) that "there is one and only one social responsibility of business - 
to use your resources and engage in activities designed to increase profits, as long as you stay within the rules of the game, engages in open and free competition without deception or fraud. "He argued that the company is responsible for maximizing the value for owners by making as much money, and that this is their moral duty. Immoral is, however, putting social and environmental objectives over profit.

In Friedman's rhetoric fits today many economists. Elaine Sternberg (1994) opines that the use of business resources for purposes unrelated to business activity is not justified. Similarly believes Aneel Karnani (2010) in his article published in the Wall Street Journal. He states that action to the public is not an obligation or duty to the company. He notes that evidences presented publicly by the company of socially responsible projects are false. The real reason for taking a socially responsible attitude is prosaic - to maximize profit (Dembińska, 2014). Corporate social responsibility is used as an effective tool of marketing (Dembińska, 2013).

Peter Fleming and Marc T. Jones (2013) called social responsibility as "a kind of alibi for business." Moreover, they believe that it is ended before it really started, because it does not bring any significant changes in the economy. The same arguments against social responsibility can be found in the article by Clive Crook (2005), which appeared in 2005 in a special issue of The Economist, devoted exclusively to social responsibility. He called social responsibility as "a license to hide" and indicates that the application of its principles brings only cosmetic changes.

Clearly declarative character, manipulative and dishonest message of social responsibility are pointing by William S. Laufer (2003), John Roberts (2003), Ronald R. Sims and Johannes Brinkmann (2003). The theoretical nature, detachment from the realities of everyday business allege, among others, Kunal Basu and Guido Palazzo (2008), Olivier Boiral (2007), and Farzad Khan, Kamal Munir and Hugh Willmott (2007).

David Henderson (2001) called social responsibility for the "wrong virtue", stating that corporate social responsibility requires voluntary acceptance by the wider business objectives, the use of complex procedures and more demanding standards, and all of this could weaken the economic parameters of the company. He believes that social responsibility causes excessive pressure on businesses and threatens excessive dependence of efficient allocation of resources from external interference.

Indicated authors are a representation of, undoubtedly, a wider group. Mention more comments expressing doubts and criticisms in relation to social responsibility, due to the limited volume of studies is difficult. Therefore, based on the revision of contemporary literature, you can make a summary of views:

1. The basic doubt is whether companies in general should deal with social responsibility? Is the essence of business activity, the purpose for which the company operates on the market, are not discrete delimitation? It seems that there is no such danger. Still, it is clear that the essence of the company is completed the production function or service, depending on the profile of the business, and the original purpose of the operation is profit. Social activities are not implemented as activities from the core business. Rather they define criteria that a company can be guided in carrying out their basic tasks. Moreover, they are expanding the scope and introduce new contexts of relationship with the environment and with stakeholders.

The issue of whether companies should take social responsibility or not, also seems to be clear. Constantly emphasizes the voluntary nature of social responsibility. There is no settled law that would suggest to implementation of social responsibility. In this range there are no standards, which are mandatory. The issue is whether to treat social responsibility as a duty, necessity or informal fashion. In other words, which attitude should adopt a company for social responsibility, which is obviously related to the motives of this attitude. 
2. Reflecting on this, that social responsibility regarded as a duty or an informal necessity it can be stated that the duty is related to the responsibility of voluntary and reflected the attitude of the contribution, while the informal necessity is related to the liability imposed and enforced and can manifest an attitude of resistance, obligation or reaction.

How can you argue a duty to be socially responsible? Conducting business operations means that it is included in a given reality, which is very often complex system of events, processes and relationships occurring in belonging to its subjects and between them. In this system they are realized and are implemented various signs and personal values. The company intervenes in such a reality, having already shaped the character and structure, leading economic activity. Any interference of enterprise is always a greater or lesser violation of the existing order, which results in some changes - both positive and negative. The balance of these changes, that is, which ones prevail, depends on the form and strength of interference, which is based on awareness of company in respect of that interference. There is no interference with the only positive consequences. In other words, there will always be some negative changes. This situation creates a cause-and-effect responsibility of company for their economic actions and decisions. Undoubtedly, a sense of duty in this context stems from a sense of guilt, and thus - the question of whether company would take social action without any reasons, if they do not feel guilty for their negative impact on the reality in which they are established, appear to be rhetorical. Following this line of reasoning, there is a problem of proportionality of responsibility to the size of the negative effects of business operations. You could set up a relationship directly proportional, but in order to it could work in practice, it would create some negative impacts of company on social environment together with an indication that in connection with the occurrence of an impact you should do this or that. In other words, it would codify a list of negative impacts of companies in the field of social activities carried out in return. And it is rather difficult to do, if only because of the complexity of interactions.

3. In the context of typology of attitudes emerges a question - if you can qualify companies to socially responsible and irresponsible in the system of zero-one, i.e. satisfies the condition - does not satisfy the condition? It is said in fact "socially responsible company", without specifying the level of responsibility. It may suggest the suspicion that it is enough to do anything to be recognized as a socially responsible company. What are the minimum eligibility frameworks to attitude the company as a socially responsible? The question is even more difficult if you bring up the voluntary nature of social responsibility.

4. Doubts about corporate social responsibility come down also to the perception of it in terms of "wishful thinking". Underlying this perception is not convinced of its effectiveness. It is hard to disagree with such thinking, because the principles and social activities, as practice shows, are real. Quite another problem is the ability to achieve them. And here you can agree with another charge that managers are not always equipped with appropriate powers to carry out the company according to the canon of social responsibility, and that sometimes these actions are intuitive, which may affect the accuracy of decisions. However, this is not an argument so important to act against social responsibility. You can certainly argue that the good intentions are sufficient. However, it is expected that the promotion of social activity will result in a short time to extract the organizational structure of enterprises separate managerial positions responsible for issues of social responsibility.

5. Very often they discussed is subjected to the question of who, really, is responsible? Is there a correct formulation of 'responsible business' or 'responsible company'? The starting point in this case is the reasoning Friedman's arguments. M. Friedman stuck with the view that only men may be responsible, as neither business nor the company are not persons and are only artificial, abstract responsibility. This argument seems to be 
correct, because the people are responsible for their actions and decisions. Therefore, it can be assumed that the formulation of corporate social responsibility is shorthand, which absolutely does not relieve people of responsibility. At the same time, there is no need for a conceptual revolution, just to clarify that people are carriers of responsibility. However, agreeing that responsibility lies with the people, there is another question - whether all employees of companies are responsible for the negative impact of companies on social environment or liability should apply only to the owner or principal managers? After all, they manage the activities and approve and take decisions in the enterprise. It seems that you cannot completely shift the responsibility on the owner or management, because it would mean that employees carry out their tasks, having no impact on their course and their effects. All employees of companies, including the owner and managers should take the attitude of socially responsible, whereby owner and managers will need to take a lead role.

6. Opponents of social responsibility emphasized that the intentions of companies that take social action, are not sincere. They are adulterated or apparent. They indicate that companies use corporate social responsibility only for marketing purposes, in addition, in a consciously calculated way, thus revealing its double standards. It is alleged that if the actions of social responsibility were not profitable, companies would not take them. Must admit that social activities work well as public relations tools and, as earlier stated, this should not be sought as something bad. As far as social effects are achieved, there is no need to prohibit companies using social responsibility also for other purposes. And settlement of the issue of double standards, you can start from doubt whether the business is marked by moral motives. Selecting position in this dispute depends on the interpretation of what is appropriate and what is not. This in turn is determined by the adopted system of values, which, as is known, may be different, depending on the context, place, time, etc.

7. Often, in critical discussions about social responsibility, is recalled the topic of cost. It is argued that corporate social responsibility costs too much. Costly is not only the introduction of the strategy of social responsibility in the functional area of companies, but above all, its actual realization. In this respect it is pointed out problem of contrary to the objective of minimizing costs. Another problem, which in this case refers, relates to compete. It compares the possibility of competing companies that take social action, and thus incur the respective costs, with the company, which does not engage in corporate social responsibility. In this context, social responsibility is seen as a limiting factor for the competitiveness of companies. Counterargument to such accusations may be the fact that the current field of competition is very broad and is not limited to the cost. In this field becoming increasingly important, as practice shows among European and global companies, organizational culture. This allows you to think about social responsibility as a factor of competition. There is no denying that the activities carried out within the framework of social responsibility are cost carrier, but you should wonder on what can be done to gain competitive advantage through these activities. It should be emphasized that customer awareness of corporate social responsibility also becomes bigger. Consequently, whether company meets the objectives of social responsibility or not, it is today in the canon of the factors determining the selection of a supplier or business partner.

8. Critical remarks are also recognized to norms and standards. It denies the possibility of the development of global guidelines in ISO 26000. The problem is that it is subjected to the question whether it is possible to establish a global system of values. National standards, apply to a national social group and its national values. International standards may apply to different national societies and make sense when they are limited to the shared values of the peoples in the region. Global standards must therefore apply to all groups of society and be 
determined on the basis of global social values, and such a set of social values has not been found yet. You can only talk about some common elements.

\section{Empirical study of the attitudes of the TSL companies towards social responsibility}

\section{Method}

The research was part of a research project of the National Science Centre 2011/01/B/HS4/05088, entitled Corporate social responsibility of TSL sector in Poland - diagnosis and futures challenges. The project was implemented in the years 2011-2013. The study was conducted from October 2012 to May 2013, using the technique of computer-assisted telephone interviewing (CATI). The geographical scope of the study included the Polish territory. The study included the following populations: companies providing logistics services, transportation and shipping operating on Polish territory on the day of the study. The survey was attended by 391 companies. The standard error of the fraction with a confidence level $\alpha=0.05$ is $5 \%$.

Sampling took place with the condition of representativeness of the results from the sample. The main purpose of sample selection was the ability to generalize the results of research to the entire study population / general, with a probability equal confidence interval - in the case the research of $95 \%$.

In the sample, the share of large enterprises amounted to $4.8 \%$ (Figure 1). Most were micro-enterprises $-54.7 \%$.

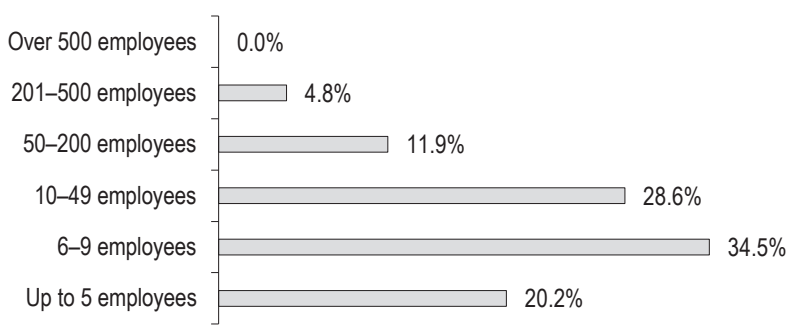

Figure 1. The structure of the study population by the number of employees Source: author's compilation.

To maintain the requirement of representativeness, the sample was separated employing the random stratified selection - proportional. For the study of social responsibility in enterprises of TSL population was divided into layers by such features as:

- the type of services: logistics, transportation, freight forwarding,

- company size: large, medium, small,

- the location of the seat of companies: on the basis of the administrative division of Polish,

- the period of operation of the market,

- operating range.

Controlled variables were the type of service and size of the company. Within each layer, the selection of the respondents was made at random. 


\section{Results}

In assessing the level of progress of implementation of the strategy of social responsibility in companies in the TSL sector in Poland, the results (Figure 2) indicate that almost half (44\%) of companies do not see the need to implement principles of social responsibility. Only $22.6 \%$ of the companies confirmed the implementation of the principles of social responsibility, while in $13.1 \%$ of cases actions do not have a formalized form.

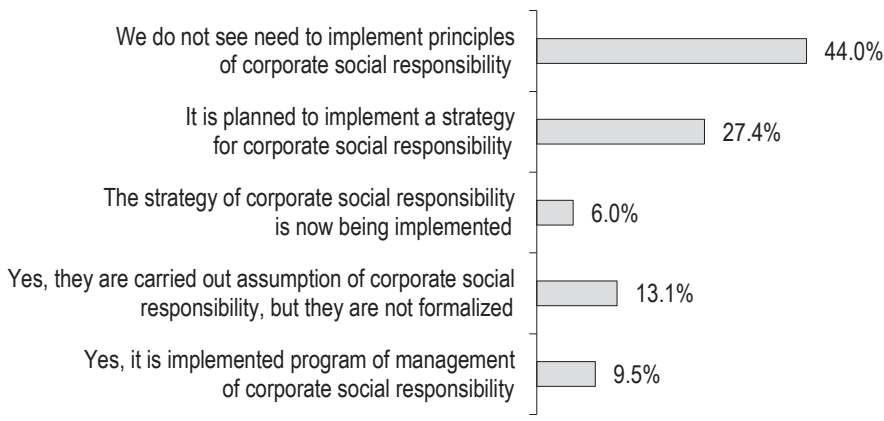

Figure 2. Level of implementation of the strategy of social responsibility in companies of TSL

Source: author's compilation.

Asking about the reason for failure to principles of social responsibility (Figure 3), most companies, up 42.9\%, indicated that they are too small. Another important reason for the lack of interest in the activity in the area of social responsibility is the need to sacrifice time. For this reason, indicated $25.7 \%$ of the companies. An equally large group of companies, ie. $20 \%$ do not perceives social responsibility benefits. Benefits are generally understood, without specifying a generic layer. The obstacle turns out to be the high costs of actions undertaken in the framework of social responsibility. At this answer indicated $8.6 \%$ of companies that have declared no need to implement principles of social responsibility. Only in $2.9 \%$ of cases assertive attitude of companies towards social responsibility stems from the lack of knowledge of how to implement such a strategy.

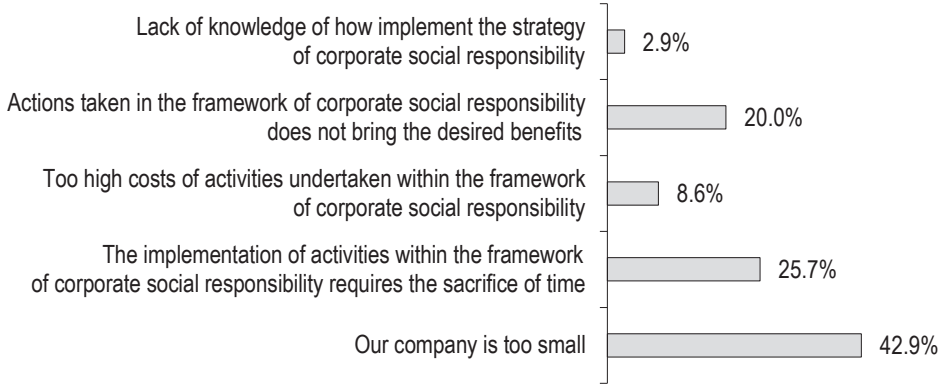

Figure 3. The reasons for not implementing the strategy of social responsibility in companies of TSL

Source: author's compilation. 


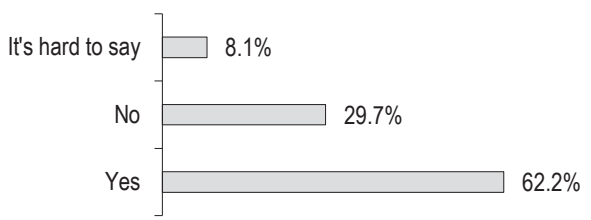

Figure 4. Percentage of enterprises of TSL, planning the implementation of the strategy of social responsibility Source: author's compilation.

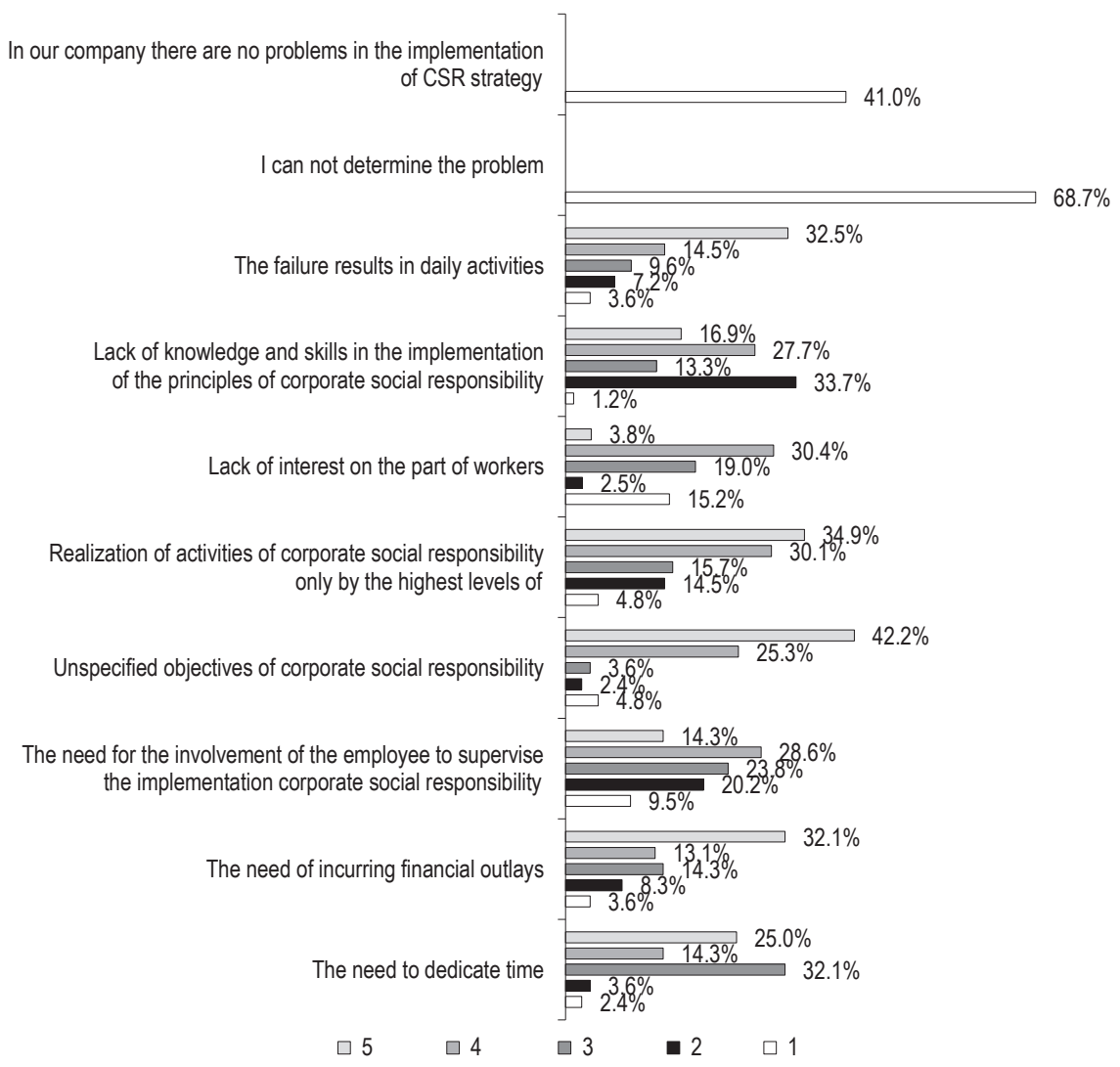

Figure 5. Problems noticed in enterprises in the implementation of the principles of corporate social responsibility (5 - the highest level of validity)

Source: author's compilation.

In the case of mentioned earlier response is difficult to determine whether the identified reasons implication is completely critical attitude of companies towards social responsibility or may need to be considered in the category of objections. Analysing the data shown in Figure 4, it can be assumed that in most cases these are not objections. 
Asking in fact that the companies are planning to implement a strategy for social responsibility more than half of them (62.2\%) answered in the affirmative. Negatively refers to the question almost $30 \%$ of the companies. This group includes companies that previously argued primarily that they are too small to implement the strategy of social responsibility, as well as that they do not see the benefits of such activities.

Objections to social responsibility may occur not only in the case of companies which have not yet implemented, but also can be reported by those companies that already implementing the strategy of social responsibility. When asked what the most important problems are perceived in enterprises in the implementation of the principles of social responsibility mentioned most often: vaguely defined objectives of social responsibility $-42.2 \%$, the need for financial expenditure $-32.1 \%$, not recognizing the effects of the daily activities of the company $-32.5 \%$, the need to dedicate time $-25.0 \%$. Relatively low important problem is the lack of knowledge and skills in implementing the principles of social responsibility to apply them in practice. It is interesting that as many as $68.7 \%$ of companies cannot identify problems associated with the implementation of social responsibility. No fewer interesting is the fact that $41 \%$ of enterprises do not notice such problems at own company.

\section{Discussion on the basis of test results}

The essential question that arises as a result of the analysis of behavior of companies in the TSL sector in relation to the strategy of social responsibility is whether the identified attitudes are typical for the test group of companies? In other words, whether they are typical of attitude for operators in the sector of TSL? Another question concerns the causes of these attitudes - whether they should be treated in a general way, or are specific to this area of business? Getting the answers to these questions requires a reach for the results of other studies, where a layer of problems is the same. It is reasonable to refer to studies in which the random sample was not differentiated by type of activity, as well as research, conducted on a random sample consisting of companies representing one kind of economic activity.

Answering the first question, you can rely on the results of a survey conducted by the Polish Agency for Enterprise Development, entitled "Evaluation of the implementation of the standards of corporate social responsibility", made in 2011. The data indicate that $70 \%$ of the representatives of large companies are aware of the concept of CSR, and $84 \%$ of them have implemented the strategy of corporate social responsibility in their business. The situation is worse in the case of micro and small companies. Understand the concept of CSR declared only $26 \%$ of companies in the group, and the use of corporate social responsibility strategy $-36 \%$.

Other studies conducted in the SME sector of agribusiness in rural areas (Wołoszyn, Stawicka, Ratajczak, 2011) confirm the results referred to above. At the same time, they provide the answer to the second question. They show a very poor knowledge of the concept of social responsibility among entrepreneurs of agribusiness industry. More than half of as much as $60 \%$ of respondents admitted that they do not know the concept of CSR. Only $16 \%$ of entrepreneurs confirmed unequivocally that, the principles and standards of corporate social responsibility are known to them ( $24 \%$ of entrepreneurs said that rather know the concept of CSR).

What are the biggest barriers to the implementation corporate social responsibility in a small or medium-sized company? In this case, the results of research carried out in a group of companies from the TSL coincide with the results of other studies and the opinions widely available. The greatest obstacle is the lack of funds and lack of time. Important, though already less, is the lack of awareness and knowledge of not just corporate social responsibility in general terms, but in terms of its potential of utility and methods of its use. You can also note that representatives 
of small and medium-sized companies do not have sufficient knowledge of what assistance can benefit in the implementation of the strategy of social responsibility, both substantive assistance and financial aid.

\section{Conclusions}

On the basis of the considerations set out in the paper, one can formulate general conclusions:

1. A way for understanding corporate social responsibility influences how it is treated in the sphere of not only cognitive, but also emotional. This in turn shapes the form and direction of behavior of entrepreneurs against it.

2. The higher is the level of awareness of corporate social responsibility, the more formalized form take action in their respective areas as well as they are more integrated territorially.

3. In the TSL sector, corporate social responsibility is not a popular strategy yet, although there are reasons to believe that this strategy will be gradually implemented by a growing number of companies. You can see a clear distinction between large enterprises, with a strong market position, which consciously pursued a strategy of corporate social responsibility, and small and medium-sized companies that see the need to implement such a strategy.

4. An attitude of SME in the sector of TSL does not deviate from attitudes of SMEs in other industries. They are also similar to the behavior that can be observed in other European countries, which means that the problem of poor activity of SMEs is not only a problem in Poland, is set at the level of the European Union.

There are also some questions for further discussion:

1. To stimulate the activity of small and medium-sized companies in the field of CSR activities, regardless of the industry, you should seek answers to the questions - how to encourage SMEs to implement the strategy of corporate social responsibility, what instruments use to effectively stimulate their activity, who should be responsible for this?

2. One may be wondering if perhaps the behavior of SMEs is correct. Maybe corporate social responsibility, by nature, should be reserved for large companies? Maybe the representatives of SMEs have a right to believe that the strategy of corporate social responsibility will not bring benefits for their business, and although it is not worth to invest in it.

\section{References}

Basu, K., Palazzo, G. (2008). Corporate Social Responsibility: A Process Model of Sensemaking. Academy of Management Review, $33(1), 122-136$.

Boiral, O. (2007). Corporate Greening Through ISO 14001: A Rational Myth? Organization Science, 18 (1), 127-146.

Crook, C. (2005). A Survey of Corporate Social Responsibility. The Economist, 22 January.

Dembińska, I. (2013). Marketingowa orientacja działań CSR na przykładzie firm logistycznych. Zeszyty Naukowe Uniwersytetu Szczecińskiego. Problemy Transportu i Logistyki, 23, 145-165.

Dembińska, I. (2014). Społeczna odpowiedzialność w przedsiębiorstwach sektora TSL: analiza postaw w świetle badań. Logistyka, 5 , 1773-1785.

Fleming, P., Jones, M.T. (2013). The End of Corporate Social Responsibility, Crisis and Critique. London: Sage Publications.

Friedman, M. (2002). Capitalism and Freedom. University of Chicago Press.

Friedman, M. (1970). The social responsibility of business is to increase its profits. The New York Times Magazine, 13th September.

Henderson, D. (2001). Misguided Virtue: False Notions of Social Corporate Social Responsibility. New Zealand Business, Roundtable. 
http://www.ewaluacja.gov.pl/Wyniki/Documents/Ocena_stanu_wdrazania_standardow_spolecznej_odpowiedzialnosci_ biznesu_13022013.pdf (12.01.2018).

Karnani, A. (2010). The Case Against Corporate Social Responsibility. Wall Street Journal, 23 August.

Khan, F.R., Munir, K.A., Willmott, H. (2007). A Dark Side of Institutional Entrepreneurship: Soccer Balls, Child Labour and Postcolonial Impoverishment. Organization Studies, 28 (7), 1055-1077.

Laufer, W.S. (2003). Social Accountability and Corporate Greenwashing. Journal of Business Ethics, 43 (3), $253-261$.

Ocena stanu wdrażania standardów społecznej odpowiedzialności biznesu (2011). Raport PARP. Warszawa, 9 December.

Roberts, J. (2003). The Manufacture of Corporate Social Responsibility: Constructing Corporate Sensibility. Organization, 10 (2), 249-265.

Sims, R.R., Brinkmann, J. (2003). Enron ethics (Culture matters more than codes). Journal of Business Ethics, 45 (3), $243-256$.

Sternberg, E. (1994). Just Business. London: Little, Brown Book Group.

Wołoszyn, J., Stawicka, E., Ratajczak, M. (2011). Społeczna odpowiedzialność małych i średnich przedsiębiorstw agrobiznesu z obszarów wiejskich. Warszawa: Wydawnictwo SGGWa.

Cite this article aS: Dembińska, I. (2018). Doubts of the TSL Enterprises to Social Responsibility - An Empirical Study Based on the Results of Research. European Journal of Service Management, 3 (27/1), 53-62. DOI: 10.18276/ejsm.2018.27/1-07. 